\title{
IDENTIFIKASI PERSEPSI GURU SWASTA DALAM MEMILIH PROFESI GURU: STUDI KASUS DI SMA SWASTA KOTA MALANG
}

\author{
Ralaivao Hanginiaina Emynorane', Muhammad Huda AY ${ }^{2}$, I Nyoman Sudana Degeng ${ }^{3}$, \\ Achmad Supriyanto ${ }^{4}$ \\ Fakultas Ilmu Pendidikan, Universitas Negeri Malang \\ emymorane@gmail.com,muhammad.huda.fip@um.ac.id \\ nyoman.sudana.d.fip@um.ac.id, aspriess@gmail.com
}

\begin{abstract}
Abstrak
Memilih profesi merupakan keputusan yang paling sulit dan kompleks dihadapi semua orang dalam kehidupan dan bukan semua orang bisa berhasil untuk memilih profesi yang tepat. Kesalahan dalam memilih profesi bukan hanya mempengaruhi kehidupan profesional tetapi dapat juga menyebabkan hambatan bagi kehidupan pribadi. Oleh karena itu diperlukan rencana yang matang sebelum memilih profesi. Penelitian ini melibatkan 16 guru dari SMA Swasta di Kota Malang dengan tujuan untukmengidentifikasialasan merekadalammemilih profesi guru dan harapanmereka setelah menjadi guru.Penelitan ini menggunakan metode kualitatif deskriptif dan teknik pengumpulan data meliputi observasi lapangan dan wawancara mendalam. Hasil temuan dari penelitian ini menunjukkan bahwa, alasan guru untuk memilih profesi mengajar adalah: (1) passion untuk mengajar, (2) senang berinteraksi dengan anak-anak, (3) banyak jumlah pekerjaan yang tersedia dalam sistem pendidikan, (4) renumerasi, gaji dan tunjangan, (5) status sosial guru di depan masyarakat, (6) saran dari keluarga, (7) alumni sekolah, (8) profesi guru adalah karir jangka panjang dan solusi jangka pendek, (9) mencari pengalaman, dan (10) kesempatan belajar. Sedangkan harapan guru dari SMA Swasta di Kota Malang adalah: (1) memiliki standar hidup yang cukup, (2) dukungan fasilitas pembalajaran yang lengkap, dan (3) dukungan fasilitas studi lanjut.
\end{abstract}

Kata kunci: persepsi, profesi guru, harapan guru, guru honorer

\begin{abstract}
Choosing a profession is the most difficult and complex decision to be taken inlife and not everyone can succeed to choose the right profession. Wrong career choice not only affect the professional life but may also damage the entire personal life. Therefore, it is needed to be well-prepared before choosing a career. This study involves 16 teachers from the Private High Schools in Malang City with the aim of identifying their reasons for choosing the teaching profession and their expectations after becoming a teacher. This study uses qualitative descriptive methods and the data collection techniques include participant observation and in-depth interview. The findings of this study indicate that, the reasons for teachers to choose the teaching profession are: (1) passion, (2)happy to interact with children, (3) a large number of jobs opportunity in education system, (4) renumeration, salary and benefits, (5) social status, (6) family advice, (7) school alumni, (8) Teaching job is a long-term career and a short-term solution, (9) collect experiences, dan (10) learning oppurtunities. While the expectations of teachers from the Private High Schools in Malang City are: (1) to have an adequate standar of living, (2) school facilities and infrastructure support, and (3) further study opportunities.
\end{abstract}

Keywords: perception, teaching profession, teachers' expectations, honorary teachers 


\section{PENDAHULUAN}

Profesi guru bukanlah hal yang mudah dan ringan dibandingkan dengan profesi-profesi yang lain. Seorang guru bukan saja harus memiliki keahlian khusus atas materi yang mau diajarkan tetapi harus berkomitmen untuk mengorbankan semua waktunya dengan kegiatan-kegiatan pembelajaran. Sebelum mengajar guru mestinya melakukan persiapan khusus atas materi yang mau diajarkan, saat mengajar guru harus berketerampilan inovatif dan kreatif dalam penyampaian materi kepada peserta didik. Dan ketika peserta didik belum paham maksud dari materi yang diajarkan, guru yang berusaha membimbing dan menjelaskan. Belum lagi guru harus memberikan perlengkapan materi melalui tugas-tugas dan pekerjaan rumah. Saat ada ujian, masih guru juga yang harus meluangkan waktu untuk mengoreksi hasil ujian tersebut. Betapa beratnya dan beban yang semua guru rasakan.

Meskipun seperti yang dipaparkan di atas sisi berat dari tugas dan profesi guru, masih tetap banyak yang mau ingin menjadi guru. Hal-hal tersebut tidak menjadi hambatan bagi anak-anak mudah untuk memilih profesi guru. Hasil data lapangan menjelesakan bahwa yayasan pendidikan menerima lamaranlamaran kerja hampir setiap hari. Oleh karen itu, peneliti teratarik untuk memahami alasan-alasan yang mendorong anak-anak mudah pada saat ini untuk memilih profesi guru, sampai jauh mana mereka mencintai profesi mengajar ini, dan apa yang mereka harapkan setelah menjadi guru.

\section{METODE PENELITIAN}

Tulisan ini adalah hasil penelitian lapangan menggunakan pendekatan metode kualitatif deskriptif. Teknik pengumpulan data yang digunakan adalah observasi lapangan dan wawancara mendalam. Informan dalam penelitian ini merupakan guru-guru yang berstatus pegawai honorer dan pegawai tetap yayasan dari kedua yayasan swasta tertua di bawah pimpinan agama Islam dan Katolik di Kota Malang, yaitu SMA Shalahuddin Malang dan SMA Katolik St. Albertus Malang. Pilihan informan dilakukan atas saran dan rekomendasi dari masing-masing kepala sekolah yayasan. Tulisan ini dimaksudkan untuk mengkaji alasan-alasan guru dalam memilih profesi guru dan harapan mereka setelah menjadi guru.

\section{HASIL DAN PEMBAHASAN}

Untuk mencari nafkah dan memenuhi kebutuhan hidup, semua orang tentu saja perlu mempunyai sebuah profesi atau pekerjaan. Namun, memilih pekerjaan bukanlah hal yang mudahkarena bukan semua orang bisa mendapatkan pekerjaan yang cocok sesuai kemampuan dan passion dirinya (Shimoni, et al: 2018, 5). Pengembangan karir dapat dimulai dari pengalaman masa anak-anak dan dapat dipengaruhi oleh diri sendiri dan faktor lingkungan (Mudzielwana: 2015, 35). Dalam memilih suatu profesi, paling tidak ada dua unsur yang harus dipertimbangkan, yaitu passion dan latar belakang pendidikan (Wang: 2017, 114). Jika demikian, Rampa (2012: 1281) memberikan saran bahwa, jika harus memilih antara passion dan latar 
belakang pendidikan, pililah profesi yang sesuai dengan passionmu karena bekerja sesuai dengan passion akan lebih bahagia.

Mengajar adalah suatu profesi yang penting karena bertujuan untuk mengembangkan pengetahuan peserta didik sebelum mereka bergabung dengan dunia kerja (Mudzielwana: 2015, 35). Oleh karena itu diperlukan guru yang memilikipassiondalam pengajaran. Menurut Rampa (2012: 1281), guru-guru yang punya passion untuk mengajar memiliki entusias dan komitmen yang tinggi. Mereka dapat membagikan passion tersebut dengan mudah kepada teman kerja mereka. Saat bekerja dengan peserta didik, mereka memiliki rasa percaya diri untuk membawa inovasi dan perbedaan dalam pembelajaran. Dan juga mudah bagi mereka membantu peserta didik untuk mencapai tujuan pembelajaran (De Cooman, et al., 2007). Namun demikian, memiliki passion saja tidak akan cukup untuk membuat seseorang pekerja sukses dalam pekerjaannya (Hall:2009). Passion harus dilengkapi dengan kompetensi atau keterampilan. Passion bisa hilang dan berkurang sepanjang waktu, terutama ketika usia bertambah dan beban kerja semakin banyak. Guru harus selalu belajar (lifelong learners) untuk mempertahankan semangat mengajar (passion) atau rasa cinta mengajar yang sudah ada dalam dirinya (Rampa: 2012, 1282). Dengan terus belajar, guru akan tetap entusias dalam melaksanakan tugas mengajarnya sehingga selalu termotivasi untuk membagi apa yang mereka minati kepada teman kerja dan peserta didik mereka. Sebagaimana dikemukakan
Rafailă (2014: 745) bahwa, motivasi merupakan mekanisme penentuan nasib sendiri (self determination) dalam memilih dan mengarahkan karir seseorang. Motivasi adalah salah satu faktor untuk mendukung pembelajaran secara mandiri (self learning), pelatihan diri (self training), dan faktor untuk mendukung penembangan karir mengajar.

Berdasarkan hasil temuan dari lapangan, alasan-alasan guru dalam memilih profesi guru dapat diuraikan sebagai berikut:

\section{Passion untuk mengajar}

Saya memilih profesi mengajar ini karena sudah passion. Mungkin juga karena ini panggilan ujar salah satu informan dalam penelitian ini. Seorang guru yang memiliki passion untuk mengajar merasa bahawa dirinya telah mendapatkan panggilan dari Tuhan untuk menyelesaikan misi tertentu. Passion adalah faktor yang menyimbulkan motivasi (Serin: 2017, 60), dan orang yang memiliki Passion akan meluangkan banyak waktu dan tenaga dalam kegiatan yang mereka cintai atau yang mereka percaya bahwa penting(Carbonneau et al: 2008, 977). Demikian juga menurutnya Day (2004:) bahwa passion diidentifikasikan dengan harapan, perhatian, dan antusiasme, yang merupakan kunci utama dalam keefektifan pembelajaran.

Fried (2001) menggambarkan guru yang memiliki passion sebagai seseorang yang jatuh cinta pada bidang pengetahuan, semangat untuk membawa perubahan pada dunia ini, dan sangat tertarik pada potensi dan dilema peserta didik. Demikian pula, Zehm dan Kottler 
(1993) mendefinisikan guru yang memiliki passion untuk mengajar sebagai guru yang mencintai pekerjaannya. Passion sangat penting untuk pembelajaran yang berkualitas dan efektif.

\section{Senang berinteraksi dengan anak- anak}

Interaksi antara guru dan peserta didik memegang peranan penting dalam kualitas pembelajaran dan pengajaran (Pennings et al: 2018: 41). Interaksi sangat penting karena dapat memperlancarkan komunikasi (Burgoon dkk: 1995). Interaksi dalam konteks ini dapat diartikan sebagai tindakan atau pengaruh timbal balik antara guru dan peserta didik. Namun, interaksi bukan selalu berkomunikasi menggunakan suara, bisa juga dalam bentuk gaya, ekspresi wajah, atau tindakan-tindakan lain. Tujuan dari interaksi adalah untuk menjaga hubungan persahabatan, peningkatan harga diri, kesempatan untuk bersenang-senang, dan akses ke dukungan orang lain saat dibutuhkan. Tingkat interaksi guru dengan peserta didik dalam kegiatan kelas dapat menekankan minat, motivasi, dan interes peserta didik. Namun, guru harus selalu sadar bahwa interaksi ada batasnya, terutama dengan peserta didik. Guru harus selalu menjaga jarak saat berkomunikasi.

\section{Banyak jumlah pekerjaan yang tersedia dalam sistem pendidikan}

Salah satu kekuatiran mahasiswa ketika sudah dalam tahapan akhir masa studinya (saat mengerjakan skripsi) adalah soal pekerjaan. Mau bekerja apa nanti ketika sudah lulus dari kuliah?
Lowongan kerja di bidang pekerjaan lain memang ada tetapi jumlah kuota yang tersedia tidak banyak dibandingkan dengan jumlah orang peminat. Dilihat dari sisi itu, maka para mahasiswa lebih memilih ke jalur yang ada banyak ruangan. Peluang bagi mahasiswa yang baru lulus kuliah (fresh graduate) untuk diterima menjadi pendidik sangat besar dibandingkan dengan peluang diterima untuk bekerja di perusahaan-perusahaan lain. Banyaknya yayasan pendidikan membutuhkan tenaga pendidik dengan kriteria minim, tanpa pengalaman (Albulescu \& Albulescu: 2015, 10). Hal ini menjadi salah satu faktor yang diperhatikan para mahasiswa saat memilih profesi sehingga banyak yang menjalurkan diri untuk masuk dalam dunia pendidikan.

\section{Renumerasi, gaji dan tunjangan}

Tingkat tunjangan dan renumerasi yang diberikan lembaga pendidikan kepada guru lumayan banyak. Meskipun secara umum, gaji pokoknya guru itu kecil, adanya berbagai tunjangan yang diberikan oleh lembaga pendidikan kepada pendidiknya, antara lain: tunjangan kesehatan, tunjangan anak (bagi yang sudah berkeluarga), tunjangan hari raya, uang transport, voucher makan, uang sertifikasi (dari pemerintah) dan tunjangan-tunjangan sosial lainnya.

\section{Status sosial guru di depan masyarakat}

Meskipun standar hidup guru (dilihat dari sisi penghasilan) masih jauh dari yang diharapkan, guru memang masih memegang status sosial yang tinggi di depan masyarakat. Guru 
memiliki fungsi tanggung jawab moral di lingkungan masyarakat sebagaimana dikemukakan Block (2008:425) bahwa guru adalah nabi di dunia yang rusak, alat untuk mengubah dunia, dan berfungsi menghadapi posisi etis dalam dunia yang tidak bermoral (immoral world).

\section{Pengaruh lingkungan sosial}

Banyak guru yang mengaku bahwa pada awalnya tidak ingin menjadi guru tetapi dipengaruhi oleh lingkungan sosial, misalnya dapat sarankeluarga, diminta oleh kepala sekolah atau dipengaruhi oleh faktor lingkungan sosial lainnya. Hal ini dikonfirmasikan oleh beberapa guru di SMA swasta Kota Malang, "sebenarnya pemilihan profesi guru ini saran dari kakek saya sih, karena kakek saya dulu guru juga". Demikian juga menurut pendapat guruguru lain bahwa, "karena saya lulusan dari sini. SMAnya dulu dari sini (...) terus diminta oleh kepala sekolah untuk mengajar di sini. Sampai sekarang masih tetap di sini"; "Saya mengajar di sini kurang lebih 30 tahun. Pada waktu itu kami berprestasi dalam bidang Olahrga jadi diminta oleh kepala Dinas untuk mengabdi mata pelajaran Olharaga";"Awalnya sih terpaksa. Sebenarnya saya tidak ingin menjadi guru (...) tapi mungkin Tuhan kasih jalan di sinilah sebenarnya saya harus ada. Sekolah ini alma mater saya. Kakak saya bertanya kamu sudah usia berapa, apa yang kamu lakukan untuk Tuhan. Sekarang ada kesempatan kamu bekerja di ladang Tuhan, kenapa kamu tidak terima. Jadi itu dasarnya. Sebenarnya secara pribadi, saya tidak mau jadi guru".Jika seorang guru telah menjadi guru atas pengaruh dari faktor lingkungan sosial, maka harus berusaha keras dalam membangun rasa cinta, minat dan passion untuk mengajar karena tentu saja tidak mudah untuk menjalani jalur hidup yang tidak diinginkan, tidak dicita-citai sebelumnya.

\section{Karir jangka panjang dan solusi jangka pendek}

Melalui tahap-tahap yang dijalani semua guru sebelum menjadi pegawai tetap yayasan (mulai dari status kepegawaian honorer, calon pegawai tetap yayasan, sampai ke status kepegawaian tetap yayasan), dapat dikatakan bahwa profesi mengajar merupakan solusi keuangan jangka pendek. Cukup banyak guru yang memberikan bimbingan belajar atau les privat (berbayar) selain melakukan tugas mengajarnya di sekolah. Kegiatan ini dapat diartikan sebagai solusi jangka pendek bagi para guru karena tidak ada kontrak kerja yang jelas dan tidak ada kepastian jangka panjang.

\section{Mencari pengalaman}

Hasil temuan lapangan juga menunjukkan bahwa banyak guru-guru yang memilih profesi mengajar demi pengalaman kerja. Mereka belum bisa memastikan bahwa pilihan profesi mengajar ini akan terus menerus. Kebanyakan guru-guru yang baru lulus kuliah (fresh graduate) dan guru yang belum berkeluarga menyampaikan keinginan mereka untuk mau lanjut studi sehingga belum bisa memastikan kalau sampai kapan mereka akan bertahan dalam profesi guru. Mereka juga masih 
ingin mempertimbangkan profesi-profesi lain jika ada kesempatan.

\section{Kesempatan belajar}

Banyak lembaga pendidikan yang menawarkan beasiswa studi lanjut kepada guru-guru yang berprestasi. Sadar dengan kesempatan ini, ada guru yang memberikan alasan pemilihan profesi guru demi peluang melanjutkan studi yang ditawarkan sekolah-sekolah. Peluang ini cukup menarik karena guruguru diberikan kesempatan untuk mengembangkan kemampuan profesionalnya tanpa membayar apa-apa, semua biaya kuliah akan ditanggung oleh yayasan.

Jika demikian alasan guru-guru dalam pemilihan profesi guru, berikut ini adalah harapan mereka setelah menjadi guru.

Pertama, para guru berharap untuk memiliki standar kehidupan yang stabil dan cukup. Hal ini penting diperhatikan karena motivasi seorang guru untuk meningkatkan kualitas kerjanya sangat dipengaruhi oleh persoalan gaji. Sebagaimana disimpulkan oleh Prihatini (2007: 21) dalam penelitiannya bahwa, motivasi kerja yang berkurang dipengaruhi oleh tingkat gaji yang rendah (...) gaji yang layak akan mampu memenuhi kebutuhan dirinya beserta keluarganya. Demikian juga dikemukakan Anuraga (2006:56) bahwa, kinerja guru dapat dipengaruhi oleh daya tarik pekerjaan, gaji, pengetahuan, lingkungan dan suasana kerja." Artinya, pegawai yang bekerja dengan perasaan tidak stabil, semangat kerja yang berkurang, loyalitas dan moral kurang semangat tidak akan produktif, baik itu bagi dirinya maupun bagi perusahan.
Tujuan pembelajaran tidak akan tercapai tanpa motiviasi kerja yang tinggi dan hal ini akan mendorong mereka untuk berpresepsi menyesal, ingin berhenti dari profesi mengajar. Sebagaimana menurut pengalaman seorang guru berikut ini bahwa, "saya pernah merasakan tidak mau lagi untuk mengajar. Karena dilihat dari sisi pendapatan dengan pengeluaran tidak seimbang, lebih banyak pengeluaran".

Bagi guru honorer sendiri, harapannya adalah untuk mendaptkan perhatian pemerintah dalam pemberian uang sertifikasi. Namun, yang menjadi masalah adalah persyaratan untuk bisa bersertifikasi yang mengwajibkan guru honorer untuk memiliki SK pegawai tetap yayasan. Pada saat ini semakin sulit menemuhi yayasan pendidikan yang bisa menerima pegawai tetap sehingga guruguru honor harus berlompat ke sekolah kiri dan sekolah kanan untuk mencarinya. Kesempatan untuk menjadi pegawai tetap yayasan sangat kecil karena sekolah-sekolah swasta lebih selektif. Sebagaimana disampaikan seoerang guru senior di SMA Katolik St. Albertus bahwa,

"Proses untuk menjadi guru tetap yayasan masa dulu belum susah, masih gampang. Sekarang, dengan banyaknya lamaran dan peminat untuk menjadi guru, proses seleksinya jadi lebih sulit. Sekolah sangat meneliti kapasitas dan kemampuan pelamar sebelum menerima mereka untuk mengajar di sini”.

Dengan persyarataan pemerintah bahwa semua guru harus memiliki SK pegawai tetap yayasan dan juga harus memenuhi 24 jam mengajar per minggu baru bisa bersertifikasi, maka kondisi 
hidup guru honorer lebih terancam. Sekola-sekolah lebih memilih untuk memanfaatkan waktu pegawai tetap yayasan dan PNS dalam pembagian jadwal pembelajaran sehingga jumlah jam mengajaryang tersedia untuk guru honorer sedikit.Oleh karena itu, para guru honorer bersuara, memohon kepada pemerintah untuk mengevaluasi kembali persyarataan yang dibutuhkan dalam pemberian sertifikasi guru supaya, "kalau boleh, mungkin tidak diharuskan punya SK guru tetap baru bisa sertifikasi (...) harapannya SK guru tetap yayasan tidak menjadi mutlak sertifikasi guru".

Bantuan sertifikasi ini sangat berarti bagi semua guru, tanpa terkecuali karena tentu saja akan mengurangi beban hidup mereka sehingga mereka akan lebih fokus ke tugas mengajar mereka. Hasil penelitian oleh Sulton (2015: 30) mendukung kenyataan ini, ia menyimpulkan bahwa guru yang sudah bersertifikasi memiliki motivasi kerja yang lebih baik, khususnya guru yang dari yayasan pendidikan swasta, yang secara psikologis memiliki kekuatiran dengan kehilangan jabatan.

Harapan kedua adalah berkaitan dengan proses pembelajaran. Untuk mencapai tujuan pendidikan nasional, para guru berharap dukungan fasilitas sarana dan prasarana yang lengkap dari yayasan. Selain kompetensi guru dalam penyampaian materi, sarana pembelajaran memiliki peranan penting dalam proses belajar mengajar. Semakin memadai sarana dan prasarana sekolah, semakin mudah suasana kegiatan pembelajaran. Selain itu, kelengkapan sarana pembelajaran bukan hanya mempengaruhi proses pembelajaran tetapi menjadi salah satu kriteria orang tua siswa dalam memilih sekolah untuk menyekolahkan anaknya (Ibrahim et al.: 2016, 228). Jika suatu sekolah ingin mendapatkan banyak murid, cukup dengan mengoptimalkan kualitas sarana pembelajaran. Fasilitas sekolah adalah salah satu persyaratan dasar dalam pendidikan oleh karena itu kualitasnya harus diperhatikan demi keselamatan anak-anak. Orang tua kadang mempertimbangkan fasilitas sekolah sebagai kriteria pemilihan sekolah. Kondisi bangunan dan komponen sekolah yang baik dapat mendukung kemajuan proses pembelajaran di sekolah (Earthman, 2002; Mc Koy et al., 2008 dalam Ibrahim et al.:2016, 229). Pendidikan tidak akan mencapai tujuan sebagaimana yang diharapkan tanpa dukungan sarana dan prasarana, oleh karena itu diperlukan sarana pendidikan seperti buku, papan, media pembelajaran, perabot, dll... untuk membantu guru dan peserta didik (Bafadal: 2004, 30). Meskipun seorang guru harus berpenampilan yang sopan di depan peserta didik, itu tidak akan cukup jika tanpa perencanaan perangkat pembelajaran yang optimal (Corcoran \& O'Flaherty: 2017, 168).

Harapan selanjutnya adalah dukungan fasilitas studi lanjut.Banyak guru yang ingin meningkatkan kemampuan dirinya tetapi mengalami ketertabasan finansial atau waktu. Beberapa guru menangku bahwa jarang atau tidak ada sama sekali kegiatankegiatan seperti seminar, pelatihan, dan workshop di mata pelejaran tertentu. Namun, Melalui pembelajaran berkelanjutan, guru dapat meningkatkan 
keterampilan mengajarnnya, menguasai pengatahuan baru, mengembangkan kemahiran (proficiency) baru, yang pada gilirannya, akan membantu meningkatkan minat dan motivasi belajar peserta didik (Kunter: 2007, 496). Bagi guru PNS dan pegawai tetap yayasan, minat untuk melakukan studi lanjut ini sangat kecil karena mereka takut kehilangan tunjangan sertifikasi kalau jam mengajarnya kurang dari 24 jam per minggu.

\section{SIMPULAN DAN SARAN}

Berdasarkan hasil temuan dan pembahasan di atas, dapat disimpulan sebagai berikut:

Alasan guru swasta dalam memilih profesi guru, antara lain: passion untuk mengajar, senang berinteraksi dengan anak-anak, terpengaruhi oleh banyaknya jumlah pekerjaan yang tersedia dalam sistem pendidikan, renumerasi, gaji dan tunjangan, pandangan terkait dengan status sosial guru di depan masyarakat, pengaruh oleh saran dari keluarga, alumni sekolah, percaya bahwa profesi guru adalah karir jangka panjang dan solusi jangka pendek, mencari pengalaman, dan reward kesempatan belajar yang ditawarkan oleh sekolahsekolah swasta.

Harapan guru setelah berprofesi guru adalah, untuk memiliki standar hidup yang cukup, untuk mendapatkan dukungan fasilitas pembalajaran yang lengkap, dan untuk mendapatkan dukungan fasilitas studi lanjut.

\section{Saran}

1. Pemerintah diharapkan memberi perhatian khusus terhadap kondisi guru-guru pada saat ini, terutama dengan kasusnya guru honorer.

2. Yayasan pendidikan sebagai lembaga penyelenggara kegiatan pembelajaran harus selalu meningkatkan kualitas layanannya, baik layanan terhadap peserta didik maupun layanan terhadap pegawai. Yayasan pendidikan harus berusaha untuk menjamin kenyamanan semua pihak yang terlibat supayakegiatan dan proses pembelajaranberjalan dengan sebagaimana mestinya.

3. Guru sebagai agen perubahan harus selalu meningkatkan kemampuan dan keterampilannya. Diharapkan juga untuk selalu optimis dan semangat dengan apa saja tantangan yang mereka alami.

\section{DAFTAR RUJUKAN}

Albulescu, M., \& Albulescu, I. (2015). Motivational Benchmarks for Teaching Career Choice. Procedia - Social and Behavioral Sciences, 209, 9-16. Doi: 10.1016/j.sbspro.2015.11.2019

Anuraga, P. (2006). Psikologi Kerja. Jakarta: Rineka Cipta.

Bafadal, I. 2004. Manajemen Perlengkapan Sekolah: Teori dan Aplikasinya. Jakarta: Bumi Aksara.

Block, A., A. (2008). Why should I be a teacher? Journal of Teacher Education, 59 (5): 416-427.

Burgoon, J. K., Stern, L. A., \& Dillman, L. (1995). Interpersonal adaptation: Dyadic interaction patterns. New York: Cambridge University Press. 
Carbonneau, N., Vallerand, R., Fernet, C., \& Guay, F. (2008). The role of passion for teaching in intrapersonal and interpersonal outcomes. Journal of Educational Psychology, 100 (4), 977-987.

Corcoran, R. P., \& O'Flaherty, J. 2017. Executive function during teacher preparation. Teaching and Teacher Education, 63, 168-175. Doi: 10.1016/j.tate.2016.12.023

Day, C. (2004). A passion for teaching. London: Routledge Falmer.

De Cooman, R. G., et al. (2007). Graduate Teacher Motivation for choosing a Job in Education. International Journal for Education Vocation and Guidance 7 (1), 123-136

Fried, R. (2001). The Passionate Teacher: A Practical Guide. Boston: Beacon Press.

Hall, S.( 2009). How to maintain a passion for teaching. New York: Center for Enhancement of Teaching and Learning.

Ibrahim, N. M., Osman, M. M., Bachok, S., \& Mohamed, M. Z. 2016. Assessment on the Condition of School Facilities: Case Study of the Selected Public School in Gombak District. Procedia Social and Behavioral Sciences, 222, 228-234. Doi: 10.1016/j.sbspro.2016.05.151

Kunter, M., Baumert, J., \& Koller, O. (2007). Effective classroom management and the development of subject related interest. Learning and instruction, 17 (5), 494-509.

Mudzielwana, N., P. (2015). Student Teachers' Reasons for Choosing Teaching as a Career: A Case Study of First Year Students from a Rural University. International Journal of Educational Sciences 10 (1): 35-42.
Pennings, H. J. M., Brekelmans, M., Sadler, P., Claessens, .C. A., van der Want, A. C., \& van Tartwijk, J. (2018). Interpersonal adaptation in teacher-student interaction.

Learning and Instruction, 55, 41-

57. Doi:

10.1016/j.learninstruc.2017.09.005

Prihatini, I. (2007). Pengaruh Tingkat Gaji dan Pengalaman Kerja Terhadap Motivasi Kerja Guru di SMP Negeri 24 Surakarta. Surakarta: Fakultas Keguruan dan Ilmu Pendidikan, Universitas Muhammadiyah Surakarta

Rafailă, E. (2014). The Evolution of Motivation for Teaching Career during the Initial Training. Procedia - Social and Behavioral sciences, 142, 745-748. Doi: 10.1016/j.sbspro.2014.07.609

Rampa, S. H. (2012). Passion for Teaching: A Qualitative Study. Procedia - Social and Behavioral Sciences, 47, 1281-1285. Doi: 10.1016/j.sbspro.2012.06.812

Serin, H. (2017). The role of Passion in Learning and Teaching. International Journal of Social Sciences \& Educational Studies, (Vol. 4), No. 1. Doi: 10.23918/ijsses.v4i1p60

Shimoni, A., Gutentag, T., \& Gati, I. (2018). Assessing career preference cohesiveness. Journal of Vocational Behavior.Doi: 10.1016/j.jvb.2018.12.006

Sulton, S., R. (2015). Kajian kompetensi SDM guru dalam rangka meningkatkan kualitas pendidikan di Kabupaten Ponorogo. Jurnal Dimensi Pendidikan dan Pembelajaran, (Vol. 3), No. 1.

Wang, C. (2017). Finding Purpose, Passion, and Happiness in Your Profession. Journal of Medical Imaging and Radiation Sciences, 
$48 \quad$ (2), 114-117. Doi: 10.1016/j.jmir.2017.04.004

Zehm, S. J., \& Kottler, J. A. (1993). On being a teacher: The human dimension. Thousand Oaks, CA: Corwin Press. 